\title{
Source and Sink Activity during Reproductive Phase of Rice (Oryza sativa L.)
}

\author{
P. Venkata Narayana ${ }^{1 *}$, B. Sreekanth ${ }^{1}$, Y. Ashoka Rani ${ }^{1}$ and B. Krishnaveni ${ }^{2}$ \\ ${ }^{1}$ Department of Crop Physiology, ANGRAU, Bapatla, India \\ ${ }^{2}$ Department of Genetics and Plant Breeding, ARS, Bapatla., India \\ *Corresponding author
}

K ey w o r d s
Rice,
Remobilization,
Amylase, Total
Carbohydrates,
proteases, Proteins.
Article Info
Accepted:
28 October 2018
Available Online:
10 November 2018

A B S T R A C T
Source and sink activity measured after anthesis in six poplar rice cultivars. The experiment was laid in randomized block design with six cultivars MTU-1001, MTU1010, MTU-7029, BPT-2231, BPT-3291 and BPT-5204 replicated four times. After anthesis, top three leaves separately, top three internodes collectively, panicle axis and grain of main culm were sampled at seven day interval and analysed for biochemical parameters that serve remobilization of nutrients. During the initial and later halves of the sampling, there was a shift in higher amylase activity from third to flag leaves. Protease activity of leaves showed an increase in all the three leaves with age, with higher levels in flag leaves and lowest levels in third leaves. Amylase activity of the top three internodes increased till 14 DAA in MTU-1010, MTU-7029 and BPT-3291, while the increase continued till 21 DAA in MTU-1001, BPT-3291 and BPT- 5204, which later decreased in either case. Similar change in total carbohydrate contents were found in the top three internodes of main culm, which increased to a higher value and decreased later, with the exception of MTU-1010 in which increase in total carbohydrates was till 21 DAA. There were varietal differences in the total carbohydrate contents and amylase enzyme activities of panicle axis, during the sampling period. Total carbohydrate contents of panicle axis increased till 21 DAA, which later decreased. But, the amylase activity of panicle axis increased till either 14 DAA (MTU-1001, MTU-7029, BPT-2231 and BPT-3291) or 21 DAA (MTU-1010 and BPT-5204), which later decreased. Total carbohydrates and proteins of grains increased with maturity, which differed among varieties. Extent of increase in total carbohydrates of grain was higher in BPT-5204, while total proteins of grain increased to greater extent in BPT-3291.

\section{Introduction}

The relation between the source capacity of the leaves and the sink capacity of panicles affects dry matter production and determines grain yield in rice. Leaves and panicles function as the major source and sink organs of photosynthates respectively in the panicle ripening stage after heading. The mature leaf becomes an asset to the plant when it is young and mature, accumulates nutrients and exports them to growing parts of the plant during reproductive development. The flag leaf plays a very important role in grain filling in small 
grain crops such as rice (Al-Tahir, 2014). Flag leaves are major source of remobilized minerals for the grains in rice. Amylase enzyme involved in starch degradation. Amy1-1, encoded by RAmylA, is involved in starch degradation in rice leaves (Asatsuma et $a l ., 2005)$. The transcription level of RAmy2A, which encodes $\alpha$ - amylase, increases in leaf sheaths after heading in rice (Chen and Wang, 2008).

The loss in shoot weight from flowering to harvest was mostly associated with increase in panicle weight in rice. The distribution of pre anthesis accumulated carbohydrates in stems plays an important role in grain filling in highyielding rice populations ( $\mathrm{Fu}$ et al., 2011). Generally, the contribution of culm carbohydrate to grain carbohydrate accumulation is $20-40 \%$ in rice (Venkateswarlu, 1976). Activity of amylase enzyme in rice culm increased sharply during starch depletion while the soluble protein level was steady (Perez et al., 1971). Ishimaru et al., (2004) reported that $\alpha$-amylase activity is consistent with the starch degradation in leaf sheaths at the heading stage of rice.

Grain yield of rice is determined by the amount of carbohydrates accumulated after heading in rice (Matsushima, 1957). In rice $68 \%$ of carbohydrates present in vegetative parts are translocated to the grain, $20 \%$ was lost by respiration and $12 \%$ remained in the vegetative parts at harvest (Cock and Yoshida, 1972). Photosynthesis in rice plants during the grain-filling period contributes $60-100 \%$ of the final grain carbon content (Yoshida, 1981). Mori et al., (2010) reported in rice that Grain protein content (GPC) is correlated with plant nitrogen concentration at various growth stages. Protein degradation is carried out by protease. It catalyse the hydrolysis of peptide bonds (Hoorn, 2008). Increased activity of proteases are noticed after anthesis.

\section{Materials and Methods}

The experiment was conducted during kharif, 2017 as a field experiment in field No.49 of Southern Block at Agricultural College Farm, Bapatla, Guntur district, Andhra Pradesh. Six rice cultivars were chosen for this experiment. The seed material of MTU varieties MTU1001, MTU-1010 and MTU-7029 was procured from Andhra Pradesh Rice Research Institute (APRRI), Maruteru and BPT varieties BPT-2231, BPT-3291 and BPT-5204 from Rice Research unit, Bapatla. Randomized block design was adopted with six rice cultivars as treatments, each replicated four times. Plant samples were collected destructively from anthesis onwards till harvesting at weekly intervals. From each plot 5 hills are pulled out and top three leaves, top three internodes, panicle axis and grains were separated from main culm of each hill and immediately placed in ice box. The plant samples transferred immediately to the defreeze conditions in the laboratory for further analysis.

Amylase activity was estimated according to the method of Thimmaiah (2012), $1 \mathrm{~g}$ of sample material 5-10 volumes of ice cold $10 \mathrm{mM}$ calcium chloride was added and kept overnight at $4^{0} \mathrm{C}$. Later, the mixture was centrifuge at $12400 \mathrm{rpm}$ at $4^{0} \mathrm{C}$ for $20 \mathrm{~min}$ and the supernatant was used as enzyme source. Protease activity in the leaf sample was determined by the method described by Anson (1938) and Folin and and Ciocalteu (1927). The total carbohydrate content was estimated by the method of Hodge and Hofreiter (1962).

\section{Results and Discussion}

Table 1 shows top three leaves of six cultivars gradual increase in amylase activity was observed. At 7 and 14 DAA amylase activity was high in third leaf followed by second and flag leaf, while at 21 and 28 DAA high in flag 
leaf followed by second and third leaf. The extent of increase was 2.6 to $4.5,2.8$ to 3.7 and 2.0 to 3.0 times in flag, second and third leaf, respectively with the progression of grain filling. This increase in flag leaf was more in MTU-1001 and less in BPT-2231. In second leaf, less in MTU-7029, BPT-3291 and more in MTU-1001, BPT-5204. In third leaf, less in BPT-5204, BPT-2231 and more in BPT-3291, MTU-1010. In rice leaf sheath at 5 DAA, amylase activity was found higher in second leaf than in flag leaf and it is consistent with starch degradation at heading stage (Ishimaru et al., 2004 and Asatsuma et al., 2005). High Amylase activity after heading in rice was reported by Sugimura et al., (2015).

Table 2 shows the increase in protease activity in MTU-1001 from 7 to 28 DAA, was 6.8, 5.7 and 4.5 folds in flag, second and third leaf, respectively. In MTU-1010, this increase was 11.0, 7.8 and 5.6 folds in flag, second and third leaf respectively. In MTU-7029 activity of protease increase by 8.0, 5.6 and 4.0 folds in flag, second and third leaf, respectively. BPT-2231exhibited 9.6, 6.6 and 5.0 folds increase in flag, second and third leaf respectively. In BPT-3291, the increase noticed was 9.2, 7.1 and 3.5 folds in flag, second and third leaf, respectively. BPT-5204 exhibited 12.0, 7.0 and 4.2 folds increase in flag, second and third leaf respectively. Increased protease activity in rice leaves during grain development period was reported by Biswa and Choudhuri (1980) and Ray and Choudhuri (1983).

Table 3 confirms that amylase activity in culm increased from 7 to 21 DAA in cvs. MTU1001, BPT-3291 and BPT-5204, then declined. In MTU-1010, MTU-7029 and BPT2231 it increased up to 14 DAA, then declined. The activity increased by 3.9 folds in MTU-1001 and BPT-3291, 3.1 in BPT-5204, 3.5 in MTU-1010, 5.3 in MTU-7029 and 3.8 in BPT-2231. The TCC increased up to 21
DAA in MTU-1001, MTU-1010, BPT 3291 and BPT-5204, upto 14 DAA in MTU-7029 and BPT-2231 and then decreased. This decline was $75.5,67.3,62.3,53.9,53.4$ and 59.8 per cent in the order of cvs. 1 to 6 respectively. Yang et al., (2001) and Perez et al., (1971) reported that amylase activity in rice culm increased after anthesis. Yoshida and Ahn (1968) stated that carbohydrate content in culm reached the maximum level around flowering time, after which it decreased in rice. It has been reported that upto 40 per cent of carbon stored in the grain is from reserved carbohydrates of the culm in rice (Matsushima, 1957; Venkateswarlu, 1976; Cock and Yoshida 1972; Song et al., 1990).

Table 4 shows amylase activity in panicle varied significantly in six cultivars, high in MTU-7029 and low in BPT-5204 and MTU1010. It increased by 3.1 and 2.1 folds from 7 to 21 DAA in MTU-1010 and BPT-5204; 3.2, $3.5,3.5$ and 3.0 folds from 7 to 14 DAA in MTU-1001, MTU-7029, BPT-2231 and BPT3291 respectively. The increase in TCC from 7 to 21 DAA was 2.2 to 5.2 folds, high in BPT-3291, MTU-1010 and low in BPT-2231. The decline in TCC from 21 to 28 DAA was 1.5 to 3.2 folds, less in BPT-2231 and high in BPT-3291. Sixty to ninty per cent of total carbon in rice panicles is derived from photosynthesis after heading and $80 \%$ or more of nitrogen absorbed from vegetative organs before heading (Mae, 1997 and Tari et al., 2009). Weng et al., (1982) concluded that rice panicle weight increased by non structural carbohydrates (NSCs) in the culms and leaf sheaths.

Table 5 results, in the present study the total carbohydrate content in grain increased continuously in all cultivars. Among cultivars MTU-1001 had high carbohydrate content in the grain. 
Table.1 Amylase activity ( $\mathrm{mg}$ of maltose released $\mathrm{g}^{-1} \mathrm{FW} \mathrm{min}^{-1}$ ) in top three leaves of rice cultivars after anthesis

\begin{tabular}{|c|c|c|c|c|c|c|c|c|c|c|}
\hline $\begin{array}{c}\text { Days } \\
\text { after } \\
\text { anthesis }\end{array}$ & $\begin{array}{l}\text { Leaf } \\
\text { position } \\
\text { from top }\end{array}$ & $\begin{array}{l}\text { MTU- } \\
1001\end{array}$ & $\begin{array}{c}\text { MTU- } \\
1010\end{array}$ & $\begin{array}{c}\text { MTU- } \\
7029\end{array}$ & $\begin{array}{l}\text { BPT- } \\
2231\end{array}$ & $\begin{array}{l}\text { BPT- } \\
3291\end{array}$ & $\begin{array}{l}\text { BPT- } \\
5204\end{array}$ & $\begin{array}{c}\text { SEm } \\
\pm\end{array}$ & $\begin{array}{c}\text { CD } \\
(0.05)\end{array}$ & $\begin{array}{c}\mathrm{CV} \\
\%\end{array}$ \\
\hline \multirow[t]{3}{*}{$7 \mathrm{DAA}$} & $1^{\text {st }}$ & 0.501 & 0.491 & 0.615 & 0.645 & 0.556 & 0.512 & 0.02 & 0.06 & 7.67 \\
\hline & $2^{\text {nd }}$ & 0.593 & 0.563 & 0.638 & 0.66 & 0.644 & 0.493 & 0.04 & 0.11 & 11.87 \\
\hline & $3^{\text {rd }}$ & 0.658 & 0.659 & 0.715 & 0.696 & 0.675 & 0.724 & 0.02 & 0.05 & 5.05 \\
\hline \multirow[t]{3}{*}{14 DAA } & $1^{\text {st }}$ & 0.816 & 0.772 & 1.207 & 0.881 & 1.147 & 0.839 & 0.07 & 0.21 & 14.91 \\
\hline & $2^{\text {nd }}$ & 1.54 & 1.29 & 1.70 & 1.69 & 1.46 & 1.36 & 0.08 & 0.24 & 10.62 \\
\hline & $3^{\text {rd }}$ & 1.69 & 1.42 & 1.95 & 1,91 & 1.64 & 1.72 & 0.11 & 0.33 & 12.68 \\
\hline \multirow[t]{3}{*}{$21 \mathrm{DAA}$} & $1^{\text {st }}$ & 2.28 & 1.9 & 2.06 & 1.68 & 1.7 & 1.55 & 0.12 & 0.35 & 12.42 \\
\hline & $2^{\text {nd }}$ & 2.22 & 1.96 & 1.79 & 2.09 & 1.88 & 1.74 & 0.11 & 0.32 & 10.94 \\
\hline & $3^{\text {rd }}$ & 1,79 & 1.94 & 1.57 & 1.48 & 2.04 & 1.72 & 0.06 & 0.20 & 7.38 \\
\hline \multirow[t]{3}{*}{28 DAA } & $1^{\text {st }}$ & 1.77 & 2.17 & 2.05 & 1.82 & 2.18 & 2.01 & 0.10 & 0.29 & 9.55 \\
\hline & $2^{\text {nd }}$ & 1.26 & 1.24 & 0.76 & 1.15 & 1.09 & 0.87 & 0.07 & 0.22 & 13.70 \\
\hline & $3^{\text {rd }}$ & 1.06 & 0.92 & 0.58 & 0.66 & 0.73 & 0.90 & 0.06 & 0.17 & 13.79 \\
\hline
\end{tabular}

Table. 2 Protease activity (Unit $\mathrm{g}^{-1} \mathrm{FW} \mathrm{min}^{-1}$ ) in top three leaves of rice cultivars after anthesis

\begin{tabular}{|c|c|c|c|c|c|c|c|c|c|c|}
\hline $\begin{array}{c}\text { Days } \\
\text { after } \\
\text { anthesis }\end{array}$ & $\begin{array}{l}\text { Leaf } \\
\text { position } \\
\text { from } \\
\text { top }\end{array}$ & $\begin{array}{c}\text { MTU- } \\
1001\end{array}$ & $\begin{array}{c}\text { MTU- } \\
1010\end{array}$ & $\begin{array}{c}\text { MTU- } \\
7029\end{array}$ & $\begin{array}{l}\text { BPT- } \\
2231\end{array}$ & $\begin{array}{l}\text { BPT- } \\
3291\end{array}$ & $\begin{array}{l}\text { BPT- } \\
5204\end{array}$ & $\begin{array}{c}\text { SEm } \\
\pm\end{array}$ & $\begin{array}{c}\text { CD } \\
(0.05)\end{array}$ & $\begin{array}{c}\mathrm{CV} \\
\%\end{array}$ \\
\hline \multirow[t]{3}{*}{$7 \mathrm{DAA}$} & $1^{\mathrm{st}}$ & 0.05 & 0.03 & 0.045 & 0.034 & 0.04 & 0.031 & 0.002 & 0.007 & 12.43 \\
\hline & $2^{\text {nd }}$ & 0.068 & 0.045 & 0.065 & 0.05 & 0.051 & 0.049 & 0.003 & 0.009 & 11.46 \\
\hline & $3^{\text {rd }}$ & 0.093 & 0.071 & 0.096 & 0.084 & 0.105 & 0.09 & 0.006 & 0.019 & 13.75 \\
\hline \multirow{3}{*}{$\begin{array}{c}14 \\
\text { DAA }\end{array}$} & $1^{\text {st }}$ & 0.143 & 0.133 & 0.153 & 0.121 & 0.167 & 0.154 & 0.009 & 0.026 & 11.84 \\
\hline & $2^{\text {nd }}$ & 0.174 & 0.164 & 0.161 & 0.168 & 0.185 & 0.198 & 0.007 & 0.02 & 7.55 \\
\hline & $3^{\mathrm{rd}}$ & 0.232 & 0.208 & 0.195 & 0.196 & 0.242 & 0.243 & 0.015 & N.S & 13.25 \\
\hline \multirow{3}{*}{$\begin{array}{c}21 \\
\text { DAA }\end{array}$} & $1^{\mathrm{st}}$ & 0.227 & 0.254 & 0.247 & 0.234 & 0.252 & 0.272 & 0.009 & 0.027 & 7.34 \\
\hline & $2^{\text {nd }}$ & 0.270 & 0.290 & 0.295 & 0.309 & 0.293 & 0.301 & 0.01 & 0.03 & 6.79 \\
\hline & $3^{\text {rd }}$ & 0.344 & 0.321 & 0.356 & 0.352 & 0.353 & 0.346 & 0.009 & 0.026 & 5.03 \\
\hline \multirow{3}{*}{$\begin{array}{c}28 \\
\text { DAA }\end{array}$} & $1^{\text {st }}$ & 0.338 & 0.328 & 0.346 & 0.329 & 0.370 & 0.369 & 0.012 & N.S & 6.75 \\
\hline & $2^{\text {nd }}$ & 0.383 & 0.354 & 0.367 & 0.332 & 0.363 & 0.348 & 0.011 & N.S & 6.31 \\
\hline & $3^{\text {rd }}$ & 0.422 & 0.401 & 0.386 & 0.413 & 0.369 & 0.382 & 0.013 & N.S & 6.75 \\
\hline
\end{tabular}


Table.3 Amylase activity (mg of maltose released $\mathrm{g}^{-1} \mathrm{FW} \mathrm{min}^{-1}$ ) and Total carbohydrates (\%) in culm of rice cultivars after anthesis

\begin{tabular}{|c|c|c|c|c|c|c|c|c|}
\hline \multirow[t]{2}{*}{ Rice cultivars } & \multicolumn{4}{|c|}{$\begin{array}{c}\text { Amylase activity in culm } \\
\left(\mathrm{mg} \text { of maltose released } \mathrm{g}^{-1} \mathrm{FW} \mathrm{min}^{-1}\right)\end{array}$} & \multicolumn{4}{|c|}{ Total Carbohydrate content $(\%)$ in culm } \\
\hline & $\begin{array}{c}7 \\
\text { DAA }\end{array}$ & $\begin{array}{c}14 \\
\text { DAA }\end{array}$ & $\begin{array}{c}21 \\
\text { DAA }\end{array}$ & $\begin{array}{c}28 \\
\text { DAA }\end{array}$ & $\begin{array}{c}7 \\
\text { DAA }\end{array}$ & $\begin{array}{c}14 \\
\text { DAA }\end{array}$ & $\begin{array}{c}21 \\
\text { DAA }\end{array}$ & $\begin{array}{c}28 \\
\text { DAA }\end{array}$ \\
\hline MTU-1001 & 0.291 & 0.889 & 1.16 & 0.386 & 14.8 & 23.3 & 40.8 & 10.0 \\
\hline MTU-1010 & 0.265 & 0.934 & 0.702 & 0.334 & 20.3 & 23.8 & 41.3 & 13.5 \\
\hline MTU-7029 & 0.236 & 1.267 & 0.715 & 0.272 & 14.5 & 30.0 & 27.3 & 10.3 \\
\hline BPT-2231 & 0.313 & 1.204 & 0.822 & 0.38 & 17.5 & 34.3 & 29.5 & 15.8 \\
\hline BPT-3291 & 0.174 & 0.553 & 0.679 & 0.316 & 18.3 & 27.5 & 39.3 & 18.3 \\
\hline BPT-5204 & 0.233 & 0.504 & 0.745 & 0.301 & 14.0 & 23.3 & 39.8 & 16.0 \\
\hline SEm \pm & 0.03 & 0.09 & 0.05 & 0.02 & 1.1 & 2.0 & 2.7 & 1.1 \\
\hline $\mathrm{CD}(0.05)$ & 0.08 & 0.26 & 0.16 & 0.07 & 3.2 & 6.0 & 8.0 & 3.4 \\
\hline $\mathrm{CV} \%$ & 21.07 & 19.45 & 13.22 & 13.02 & 12.9 & 14.7 & 14.7 & 16.2 \\
\hline
\end{tabular}

Table.4 Amylase activity (mg of maltose released $\mathrm{g}^{-1} \mathrm{FW} \mathrm{min}^{-1}$ ) and Total carbohydrate content $(\%)$ in panicle of rice cultivars after anthesis

\begin{tabular}{|c|c|c|c|c|c|c|c|c|}
\hline \multirow[t]{2}{*}{$\begin{array}{l}\text { Rice } \\
\text { cultivars }\end{array}$} & \multicolumn{4}{|c|}{$\begin{array}{l}\text { Amylase activity in panicle } \\
\left(\mathbf{m g} \text { of maltose released } \mathbf{g}^{-1} \mathrm{FW} \mathbf{~ m i n}^{-1}\right)\end{array}$} & \multicolumn{4}{|c|}{$\begin{array}{l}\text { Total carbohydrate content }(\%) \text { in } \\
\text { panicle }\end{array}$} \\
\hline & $\begin{array}{c}7 \\
\text { DAA }\end{array}$ & $\begin{array}{c}14 \\
\text { DAA }\end{array}$ & $\begin{array}{c}21 \\
\text { DAA }\end{array}$ & $\begin{array}{c}28 \\
\text { DAA }\end{array}$ & $\begin{array}{c}7 \\
\text { DAA }\end{array}$ & $\begin{array}{c}14 \\
\text { DAA }\end{array}$ & $\begin{array}{c}21 \\
\text { DAA }\end{array}$ & $\begin{array}{c}28 \\
\text { DAA }\end{array}$ \\
\hline $\begin{array}{c}\text { MTU- } \\
1001\end{array}$ & 0.134 & 0.425 & 0.312 & 0.286 & 12.3 & 11.8 & 44.3 & 17.3 \\
\hline $\begin{array}{c}\text { MTU- } \\
1010\end{array}$ & 0.123 & 0.349 & 0.385 & 0.252 & 8.0 & 9.8 & 40.3 & 14.0 \\
\hline $\begin{array}{l}\text { MTU- } \\
7029\end{array}$ & 0.167 & 0.582 & 0.34 & 0.406 & 7.8 & 7.0 & 32 & 14.3 \\
\hline $\begin{array}{c}\text { BPT- } \\
2231\end{array}$ & 0.14 & 0.494 & 0.278 & 0.345 & 10.5 & 12.0 & 23.5 & 16.0 \\
\hline $\begin{array}{l}\text { BPT- } \\
3291\end{array}$ & 0.128 & 0.378 & 0.318 & 0.324 & 6.5 & 9.0 & 33.8 & 10.5 \\
\hline $\begin{array}{l}\text { BPT- } \\
5204\end{array}$ & 0.125 & 0.189 & 0.268 & 0.266 & 7.3 & 13.8 & 23.0 & 12.0 \\
\hline SEm \pm & 0.01 & 0.04 & 0.03 & 0.02 & 1.0 & 0.9 & 2.6 & 1.0 \\
\hline $\mathrm{CD}(0.05)$ & N.S & 0.13 & N.S & 0.07 & 3.1 & 2.8 & 7.7 & 2.9 \\
\hline CV \% & 17.88 & 21.18 & 17.47 & 15.0 & 23.9 & 17.5 & 15.7 & 13.9 \\
\hline
\end{tabular}


Table.5 Total Carbohydrate content (\%) and Total soluble protein content $\left(\mathrm{mg} \mathrm{g}^{-1} \mathrm{FW}\right)$ in grain of rice cultivars after anthesis

\begin{tabular}{|c|c|c|c|c|c|c|c|c|c|}
\hline \multirow{2}{*}{$\begin{array}{c}\text { Rice } \\
\text { cultivars }\end{array}$} & \multicolumn{3}{|c|}{ Total Carbohydrate content $(\%)$} & \multicolumn{3}{|c|}{ Total soluble protein content $\left(\mathrm{mg} \mathrm{g}^{-1} \mathrm{FW}\right)$} \\
\cline { 2 - 9 } & $\mathbf{7}$ & $\mathbf{1 4}$ & $\mathbf{2 1}$ & $\mathbf{2 8}$ & $\mathbf{7}$ & $\mathbf{1 4}$ & $\mathbf{2 1}$ & $\mathbf{2 8}$ DAA \\
\hline DAA & DAA & DAA & DAA & DAA & DAA & DAA & \\
\hline MTU-1001 & 38.3 & 64.3 & 73.0 & 81.8 & 17.6 & 40.4 & 83.6 & 85.4 \\
\hline MTU-1010 & 34.5 & 57.5 & 73.8 & 74.5 & 17.4 & 41.0 & 83.3 & 87.6 \\
\hline MTU-7029 & 26.8 & 52.3 & 61.3 & 64.8 & 10.7 & 32.3 & 57.4 & 71.1 \\
\hline BPT-2231 & 31.0 & 45.5 & 58.0 & 75.3 & 13.1 & 38.9 & 69.5 & 75.7 \\
\hline BPT-3291 & 32.8 & 50.8 & 67.0 & 63.5 & 13.0 & 16.7 & 92.8 & 98.4 \\
\hline BPT-5204 & 23.5 & 52.3 & 58.8 & 70.3 & 12.4 & 30.4 & 75.2 & 75.9 \\
\hline SEm \pm & $\mathbf{2 . 1}$ & $\mathbf{2 . 4}$ & $\mathbf{3 . 2}$ & $\mathbf{3 . 3}$ & $\mathbf{1 . 2}$ & $\mathbf{3 . 6}$ & $\mathbf{6 . 3}$ & $\mathbf{4 . 5}$ \\
\hline CD $(0.05)$ & $\mathbf{6 . 3}$ & $\mathbf{7 . 1}$ & $\mathbf{9 . 7}$ & $\mathbf{1 0 . 1}$ & $\mathbf{3 . 5}$ & $\mathbf{1 1 . 0}$ & $\mathbf{1 9}$ & $\mathbf{1 3 . 7}$ \\
\hline CV \% & $\mathbf{1 3 . 5}$ & $\mathbf{8 . 8}$ & $\mathbf{9 . 9}$ & $\mathbf{9 . 3}$ & $\mathbf{1 6 . 5}$ & $\mathbf{2 1 . 9}$ & $\mathbf{1 6 . 4}$ & $\mathbf{1 1 . 0}$ \\
\hline
\end{tabular}

The increase in TCC of grain from 7 to 28 DAA in percentage was 53.2 in MTU-1001, 53.7 in MTU-1010, 58.7 in MTU-7029, 58.8 in BPT-2231, 48.4 in BPT-3291 and 66.5 in BPT-5204. The point enlightened in this finding is that the per cent increase in TCC of grain from anthesis to maturity was high in BPT-5204 and low in BPT-3291. It has been reported that carbohydrate after heading in rice determines grain yield (Matsushima, 1957). Cock and Yoshida (1972) reported that in rice 68 per cent of carbohydrates translocated to grain from vegetative parts. Gebbing and Schnyder (1999) stated that wheat grain $8-27 \%$ of carbon contributed from pre anthesis reserves.

Among cultivars highest protein content observed in BPT-3291 and next in MTU-1010 and MTU-1001. Protein content of grain from 7 to 28 DAA increased to 79.4 in MTU-1001, 80.1 in MTU-1010, $85.0 \%$ in MTU-7029, 82.7 in BPT-2231, 86.8 in BPT-3291 and 83.7 in BPT-5204. This suggests that the per cent increase in grain protein content from anthesis to maturity was high in BPT-3291 followed by MTU-7029 and low in MTU-1001. Gregersen et al., (2008) in barley stated that protenecious components of leaf cells degraded to amino acids and exported via phloem to the developing grain.Cruz et al., (1970) and Tsukaguchi et al., (2016) reported that the protein content per grain gradually increased after flowering in rice.

Abbreviation: DAA- Days after anthesis; FW-Fresh Weight; mg- milli grams; ggrams; min-Minutes.

\section{References}

Al-Tahir, F.M. 2014. Flag leaf characteristics and relationship with grain yield and grain protein percentage for three cereals. Journal of Medicinal Plants Studies. 2(5): 1-7.

Anson, M.L.1938. Journal of General Physiology. 22: 79-89.

Asatsuma, S., Sawada, C., Itoh, K., Okito, M., Kitajima, A and Mitsui, T. 2005. 
Involvement of $\alpha$-amylase 1-1 in starch degradation in rice chloroplasts. Plant Cell Physiology. 46: 858-869.

Biswas, A.K and Choudhuri, M.A. 1980. Mechanism of monocarpic senescence in rice. Plant Physiology. 65 (2): 340345.

Chen, H.J and Wang, S.J. 2008. Molecular regulation of sink-source transition in rice leaf sheaths during the heading period. Acta Physiologiae Plantarum. 30(5): 639-649.

Cock, J.H and Yoshida, S. 1972. Accumulation of 14 C-labelled carbohydrate before flowering and its subsequent redistribution and respiration in the rice plant. Japanese Journal of Crop Science. 41(2): 226234.

Cruz, L.J., Cagampang, G.B and Juliano, B.O. 1970. Biochemical factors affecting protein accumulation in the rice grain. Plant Physiology. 46(5): 743-747.

Folin, O and Ciocalteu, V. 1927. On tyrosine and tryptophane determinations in proteins. Journal of Biological Chemistry. 73(2): 627-650.

Fu, J., Huang, Z., Wang, Z., Yang, J and Zhang, J. 2011. Pre-anthesis nonstructural carbohydrate reserve in the stem enhances the sink strength of inferior spikelets during grain filling of rice. Field Crops Research. 123(2): 170-182.

Gebbing, T and Schnyder, H. 1999. Preanthesis reserve utilization for protein and carbohydrate synthesis in grains of wheat. Plant Physiology. 121(3): 871878.

Gregersen, P.L., Holm, P.B and Krupinska, K. 2008. Leaf senescence and nutrient remobilisation in barley and wheat. Plant Biology. 10(1): 37-49.

Hodge, J.E and Hofreiter, B.T. 1962. Determination of total carbohydrates by anthrone. Carbohydrate Chemistry. 420.
Hoorn, R.A., 2008. Plant proteases: from phenotypes to molecular mechanisms. Annual Reviews of Plant Biology. 59: 191-223.

Ishimaru, K., Kosone, M., Sasaki, $\mathrm{H}$ and Kashiwagi, T. 2004. Leaf contents differ depending on the position in a rice leaf sheath during sink-source transition. Plant Physiology and Biochemistry. 42(11): 855-860.

Lowry, O.H., Rosebrough, A.L., Farr and Randall, R.J. 1951. Journal of Biology and Chemistry.193: 265.

Mae, T. 1997. Physiological nitrogen efficiency in rice: nitrogen utilization, photosynthesis, and yield potential. Plant and Soil. 196(2): 201210.

Matsushima, S. 1957. Analysis of development factors determining yield and yield prediction in low land rice. Bulletin of the National Institute of Agricultural Sciences. 5: 1-27(1).

Mori, S., Yokoyama, K and Fujii, H. 2010. Classification of brown rice with different protein content using the diagnosis of leaf color during the ripening period in Shonai area of Yamagata prefecture. Japanese Journal of Crop Sciences. 79: 113-119.

Perez, C.M., Palmiano, E.P., Baun, L.C and Juliano, B.O. 1971. Starch metabolism in the leaf sheaths and culm of rice. Plant Physiology. 47(3): 404-408.

Ray, S., Mondal, W.A and Choudhuri, M.A. 1983. Regulation of leaf senescence, grain filling and yield of rice by kinetin and abscisic acid. Physiologia Plantarum. 59(3): 343-346.

Song, X., Agata, W and Kawamitsu, Y. 1990.Studies on dry matter and grain production of $\mathrm{F} 1$ hybrid rice in China. III. Grainproduction character from the view point of time changes in nonstructural carbohydrate and nitrogen contents during the yield production. 
Japanese Journal of Crop Sciences.59: 107-112.

Sugimura, Y., Michiyama, $\mathrm{H}$ and Hirano, T. 2015. Involvement of $\alpha$-amylase genes in starch degradation in rice leaf sheaths at the post-heading stage. Plant Production Science. 18(3): 277-283.

Tari, D.B., Gazanchian, A., Perdashti, H.A and Nasiri, M. 2009. Flag leaf morphophysiological response to different agronomical treatments in a promising line of rice (Oryza sativa $\mathrm{L}$.). American-Eurasian Journal of Agriculture and Environmental Sciences. 5: 403-408.

Thimmaiah, S.R. 2012. Standard Methods of Biochemical Analysis. 186.

Total soluble protein content in grain was estimated according to the method of Lowry et al., (1951),

Tsukaguchi, T., Nitta, S and Matsuno, Y. 2016. Cultivar differences in the grain protein accumulation ability in rice (Oryza sativa L.). Field Crops Research. 192: 110-117.

Venkateswarlu, B. 1976. Source-sink interrelationships in lowland rice. Plant and Soil. 44(3): 575-586.

Weng, J.H., Takeda, T., Agata, W and Hakoyama, S. 1982. Studies on dry matter and grain production of rice plants: I. Influence of the reserved carbohydrate until heading stage and the assimilation products during the ripening period on grain production. Japanese Journal of Crop Science. 51(4): 500-509.

Yang, J., Zhang, J., Wang, Z and Zhu, Q. 2001. Activities of starch hydrolytic enzymes and sucrose- phosphate synthase in the stems of rice subjected to water stress during grain filling. Journal of Experimental Botany. 52(364): 2169-2179.

Yoshida, S and Ahn, S.B.1968. The accumulation process of carbohydrate in rice varieties in relation to their response to nitrogen in the tropics. Soil Science and Plant Nutrition. 14(4): 153161.

Yoshida, S. 1981. Fundamentals of Rice Crop Science. International Rice Research Institute.

\section{How to cite this article:}

Venkata Narayana, P., B. Sreekanth, Y. Ashoka Rani and Krishnaveni, B. 2018. Source and Sink Activity during Reproductive Phase of Rice (Oryza sativa L.). Int.J.Curr.Microbiol.App.Sci. 7(11): 3632-3639. doi: https://doi.org/10.20546/ijcmas.2018.711.417 